\title{
Poprawa obrazowania struktur podcechsztynskich na podstawie reprocessingu sejsmiki 2D w rejonie Pomorza Zachodniego
}

\author{
Improving the imaging of under-Zechstein structures based on the reprocessing of 2D \\ seismic in the West Pomerania region, Poland
}

\author{
Łukasz Bajewski, Aleksander Wilk, Andrzej Urbaniec, Robert Bartoń \\ Instytut Nafty i Gazu - Państwowy Instytut Badawczy
}

\begin{abstract}
STRESZCZENIE: W niniejszym artykule zaprezentowano wyniki reprocessingu profili sejsmicznych 2D w rejonie Pomorza Zachodniego. Celem reprocessingu była poprawa obrazowania utworów i struktur podcechsztyńskich. Dotychczasowe wyniki przetwarzania sejsmicznego w zakresie tych utworów nie pozwalają na ich interpretację strukturalną (a tym bardziej facjalną), pomimo podejmowanych w tym celu wysiłków. Reprocessing wykonano w wersji migracji po składaniu (poststack) w oparciu o sekwencję przetwarzania opracowaną w Zakładzie Sejsmiki Instytutu Nafty i Gazu - Państwowego Instytutu Badawczego. Do migracji po składaniu zastosowano pole prędkości składania oraz pole prędkości oparte o pomiary PPS. Zapis sejsmiczny, uzyskany na przetworzonym profilu, cechuje się lepszym odwzorowaniem budowy geologicznej w stosunku do wcześniejszego opracowania. Obraz sejsmiczny uzyskany w wyniku zastosowania pola prędkości do migracji po składaniu, opartego o pomiary PPS, wydaje się być lepszy w stosunku do obrazu sejsmicznego uzyskanego w wyniku zastosowania pola prędkości do migracji po składaniu. Niemniej jednak różnice są niewielkie. Uzyskany obecnie obraz sejsmiczny ukazuje więcej szczegółów budowy strukturalnej zwłaszcza w obrębie utworów permsko-mezozoicznych. W utworach podcechsztyńskich ta różnica nie jest tak wyraźna, ale pozwala na korelację niektórych elementów strukturalnych i tektonicznych, co nie było możliwe na wersji wcześniejszej. Główną przyczyną braku czytelnego i wiarygodnego obrazu strukturalnego w zapisie sejsmicznym dla utworów podcechsztyńskich wydaje się być brak poprawnego rozkładu prędkości w tych utworach, wynikający z niedostatecznej ilości danych. Niemniej jednak wyniki tej pracy pokazują, że nadal istnieje spory potencjał w zakresie reprocessingu archiwalnych profili sejsmicznych z badanego rejonu, a wysiłki poprawy obrazu sejsmicznego w obrębie utworów podcechsztyńskich powinny się koncentrować głównie na poprawnym odwzorowaniu pola prędkości w ich obrębie.
\end{abstract}

Słowa kluczowe: migracja poststack, prędkości składania, model prędkości, PPS.

Abstract: This article presents the results of 2D seismic reprocessing in the West Pomerania region. The purpose of reprocessing was to improve the imaging of under-Zechstein formations and structures. The current results of seismic processing in this area do not allow for their structural (and more facial) interpretation, despite the efforts undertaken to this end. Reprocessing was carried out in the poststack migration version based on a processing sequence developed at the Seismic Department of the Oil and Gas Institute - National Research Institute. Stacking velocities and a velocity model based on VSP measurements were used for poststack migration. The seismic image on the reprocessed profile has a better projection of the geological structure in relation to the previous study. The seismic image obtained as a result of using the velocity model to poststack migration based on VSP measurements appears to be better than the seismic image obtained as a result of using the stacking velocities for poststack migration, but the differences are not significant. The recently obtained seismic image shows more details of tectonics, especially within the Permian-Mesozoic stage. In under-Zechstein formations this difference is not as clear, but allows for the correlation of some structural and tectonic elements which is not possible on the earlier version. The main reason of unreliable structural projection in the seismic image for under-Zechstein formations seems to be the lack of correct velocity distribution in this area, because of insufficient data. Nevertheless, the results of this work shows that there is still appreciable potential for the reprocessing of archival 2D seismic profiles from the studied region. The efforts to improve the seismic image within the under-Zechstein formations should focus on the correct mapping of the velocity field within them.

Key words: poststack migration, stacking velocities, velocity model, VSP.

Autor do korespondencji: Ł. Bajewski, e-mail: lukasz.bajewski@inig.pl

Artykuł nadesłano do Redakcji 20.12.2018 r. Zatwierdzono do druku 25.03.2019 r. 


\section{Wstęp}

Obrazowanie struktur podcechsztyńskich w zapisie sejsmicznym w rejonie Pomorza Zachodniego pod kątem poszukiwań węglowodorów jest ciągle niezadowalające. Utwory cechsztynu stanowią swoisty ekran sejsmiczny przesłaniający obraz poniżej leżących utworów paleozoicznych. Jest to główna przeszkoda w poszukiwaniach i braku odkryć w tych utworach dla tego rejonu. Wykorzystując doświadczenia zdobyte przy reprocessowaniu profilu z rejonu Karpat fliszowych w południowo-wschodniej Polsce (Bajewski et al., 2016, 2017a, 2017b, 2018a) autorzy podjęli się próby rozwiązania tego problemu. Do reprocessingu wybrano profil sejsmiczny nr 1 (rys. 3). Do przetwarzania w/w profilu wykorzystana została sekwencja przetwarzania, którą opracowano w pracach statutowych (Bajewski et al., 2016, 2017b), z modyfikacjami poszczególnych parametrów oraz doborem algorytmów. Migrację po składaniu zrealizowano w oparciu o pole prędkości składania oraz pole prędkości opracowane na bazie pomiarów PPS (pionowe profilowana sejsmiczne), które ze względu na metodykę pomiaru zawierają informację o anizotropii ośrodka geologicznego. Taka budowa pola prędkości na potrzeby migracji po składaniu została opracowana w pracy statutowej (Wilk et al., 2017, 2018). Pomiary prędkości średnich z otworów, zlokalizowanych w sąsiedztwie analizowanego profilu sejsmicznego, zostały interpolowane pomiędzy otworami i ekstrapolowane w obrębie założonej przestrzeni obliczeniowej (rys. 4). Realizację przestrzennej dystrybucji prędkości interwałowych, obliczonych z wyników pomiarów PPS w domenie czasu, wykonano w systemie Petrel firmy Schlumberger. $\mathrm{Z}$ tak skonstruowanego pola prędkości, na potrzeby migracji, zostały wyekstrahowane prędkości wzdłuż reprocessowanego profilu sejsmicznego.

Nazewnictwo otworów wiertniczych i profilu sejsmicznego zostało zakodowane, ze względu na konieczność ochrony informacji.

\section{Krótka charakterystyka geologiczna rejonu badań}

Analizowany profil sejsmiczny zlokalizowany jest w obszarze Pomorza Zachodniego. Biorąc pod uwagę jednostki tektoniczne badany rejon zlokalizowany jest w strefie tzw. szwu transeuropejskiego (Trans European Suture Zone, TESZ), biegnącego wzdłuż krawędzi kratonu wschodnioeuropejskiego (vide Pharaoh, 1999; Grad et al., 2002; Nawrocki i Poprawa, 2006) i stanowiącego obszar graniczny pomiędzy prekambryjską platformą wschodnioeuropejską, a zachodnioeuropejska platformą paleozoiczną (rys. 1). Natomiast w odniesieniu do mezozoicznego piętra strukturalnego rejon ten leży na terenie pomorskiego segmentu antyklinorium śródpolskiego (Żelaźniewicz et al., 2011).

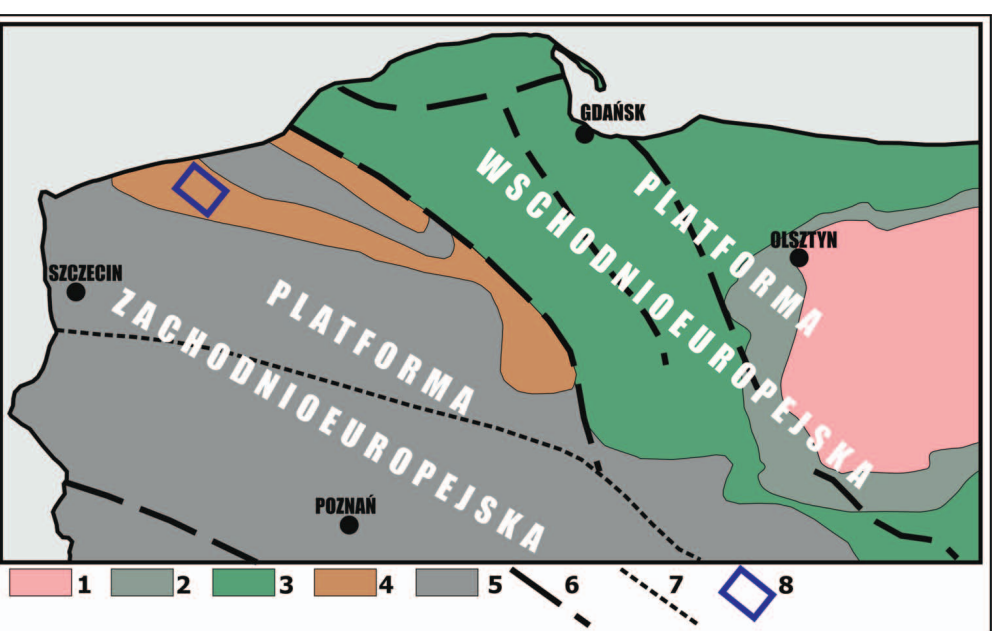

Rys. 1. Mapa głównych jednostek tektonicznych Polski pod pokrywą permsko-mezozoiczną i kenozoiczną (wg Żelaźniewicza et al., 2011): 1 - podże krystaliczne; 2 - kambr; 3 - ordowik-sylur; 4 - dewon; 5 - karbon; - główne strefy dyslokacji; 7 - zasięg zapadliska przedgórskiego warycydów; 8 - lokalizacja obszaru badań

Fig. 1. Map of the main Polish tectonic units under the Permian - Mesozoic and Cenozoic cover (according to Żelaźniewicz et al., 2011): 1 - crystalline asement; 2 - Cambrian; 3 - Ordovician-Silurian; 4 - Devonian; - Carboniferous; 6 - main dislocation zones; 7 - the range of the ariscan foredeep basin; 8 - localization of the research area
Bardziej szczegółowa budowa geologiczna obszaru badań, obejmująca poszczególne piętra strukturalne analizowanego rejonu wraz z obowiązującymi podziałami litostratygra-ficznymi przedstawiona została w pracy statutowej (Bajewski et al., 2018b). W związku z tym w ramach niniejszej pracy przedstawione zostaną tylko podstawowe ramy budowy geologicznej obszaru badań.

W obrębie analizowanego rejonu wyróżnić można trzy główne piętra strukturalne. Najstarszymi wiekowo skałami, rozpoznanymi w otworach wiertniczych $\mathrm{w}$ analizowanym obszarze, są utwory dewonu, które wraz z utworami karbonu tworzą skomplikowaną mozaikę, świadczącą o istnieniu w podłożu cechsztynu szeregu odrębnych bloków, powstałych w wyniku zdarzeń tektonicznych i erozyjnych, jakie miały miejsce w obszarze basenu pomorskiego w czasie późnego dewonu, karbonu oraz permu. Przypuszczalnie znaczna część osadów dewonu i karbonu została usunięta przez kolejne etapy erozji, będące następstwem stopniowego dźwigania się obszaru pomorskiego (vide Dadlez, 1978; Matyja 1993; Matyja et al., 2000). Istotnym aspektem budowy geologicznej Pomorza jest również wyraźne pierwotne zróżnicowanie miąższości utworów dewonu i karbonu, wynikające ze zróżnicowanej i zmiennej 
w czasie subsydencji, jaka miała miejsce w obrębie poszczególnych bloków tektonicznych (Matyja, 1993, 2006; Świdrowska i Hakenberg, 1996; Matyja et al., 2000). Na utworach paleozoicznych zalęgają utwory dolnego permu (czerwonego spągowca). Perm górny (cechsztyn) tworzą cztery główne cyklotemy: PZ1, PZ2, PZ3 i PZ4. Starsze cykle sedymentacyjne mają charakter węglanowo-ewaporatowy. Najmłodszy cykl ma natomiast charakter klastyczno-ewaporatowy. Cykliczność trzech najstarszych cyklotemów (PZ1, PZ2, PZ3) związana jest ze zmianami transgresywno-regresywnymi morza cechsztyńskiego, podczas gdy cykliczność najmłodszego cyklotemu PZ4 wynika głównie z cyklicznych zmian klimatu, gdyż w okresach wilgotnych miała miejsce sedymentacja utworów terygenicznych, a w okresach suchych utworów ewaporatowych (Wagner, 1994). Utwory cechsztynu przykrywa piętro mezozoiczne zaczynające się utworami triasu reprezentowanymi przez pstry piaskowiec, wapień muszlowy, kajper i retyk. Mezozoik kończy się utworami dolnej jury. Utwory kenozoiczne są reprezentowane przez czwartorzęd.

\section{Przetwarzanie sejsmiczne (reprocessing)}

Przetwarzanie sejsmiczne prowadzono w systemie SeisSpace (ProMax) - Seismic Processing and Analysis Release 5000.10.0.1. Do przetwarzania w/w profilu wykorzystana została sekwencja przetwarzania, którą opracowano w ramach prac statutowych (Bajewski et al., 2016, 2017b) z modyfikacjami poszczególnych parametrów oraz doborem algorytmów. Najważniejsze zmiany parametrów dotyczyły procesu filtracji sygnału sejsmicznego i dekonwolucji, doboru pól prędkości oraz thumienia fal wielokrotnych.

Blokowy schemat sekwencji przetwarzania przedstawiony został na rysunku 2.

\section{Budowa pola prędkości do migracji czasowej po składaniu}

Migrację po składaniu zrealizowano w oparciu o pole prędkości składania (rys. 4) oraz pole prędkości opracowane na bazie pomiarów PPS (pionowe profilowania sejsmiczne), które ze względu na metodykę pomiaru zawierają informację o anizotropii ośrodka geologicznego (Wilk et al., 2017, 2018). Do budowy

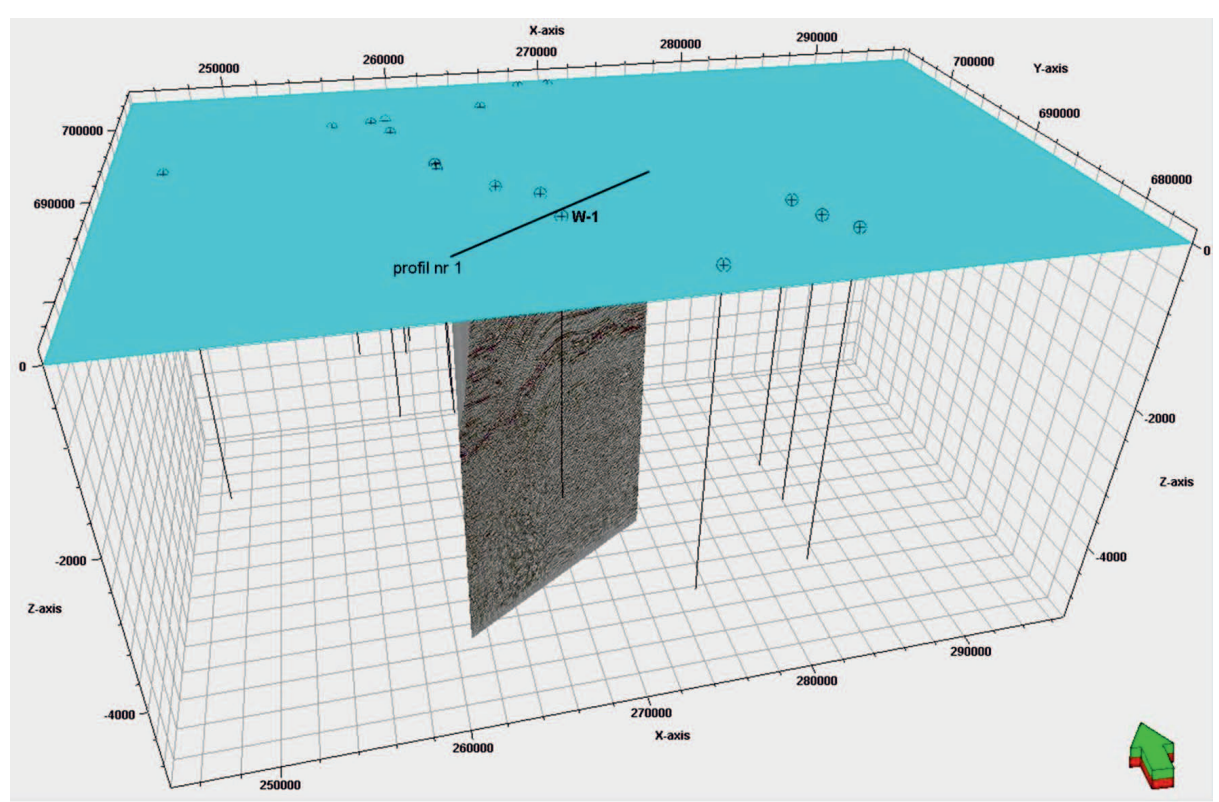

Rys. 3. Przestrzeń obliczeniowa obejmująca profil sejsmiczny i pomiary PPS

Fig. 3. 3D space calculation with seismic profile and vertical seismic profiling (VSP) 


\section{NAFTA-GAZ}

W przyjętej przestrzeni obliczeniowej rozpatrywany był model płasko-równoległy bez interpretacji strukturalnej. Spowodowane to było brakiem profili sejsmicznych, w oparciu o które taka interpretacja byłaby możliwa. Wobec powyższego rozkład prędkości w przyjętym modelu jest rozkładem liniowym. Model został podzielony na warstwy o miąższości $10 \mathrm{~m}$.

Prędkości średnie uzyskane z pionowych profilowań sejsmicznych PPS zostały przeliczone na prędkości interwałowe w skali czasu i przeskalowane do przyjętego interwału warstwowania $10 \mathrm{~m}$, a następnie ekstrapolowane i interpolowane przy użyciu algorytmów rozkładu Gaussa, Krigging i Moving Avarage w systemie Petrel firmy Schlumberger. Z tak skonstruowanego pola prędkości na potrzeby migracji, zostały wyekstrahowane prędkości wzdłuż reprocessowanego profilu sejsmicznego (rys. 5). Dla każdego pola prędkości (rys. 4, 5)

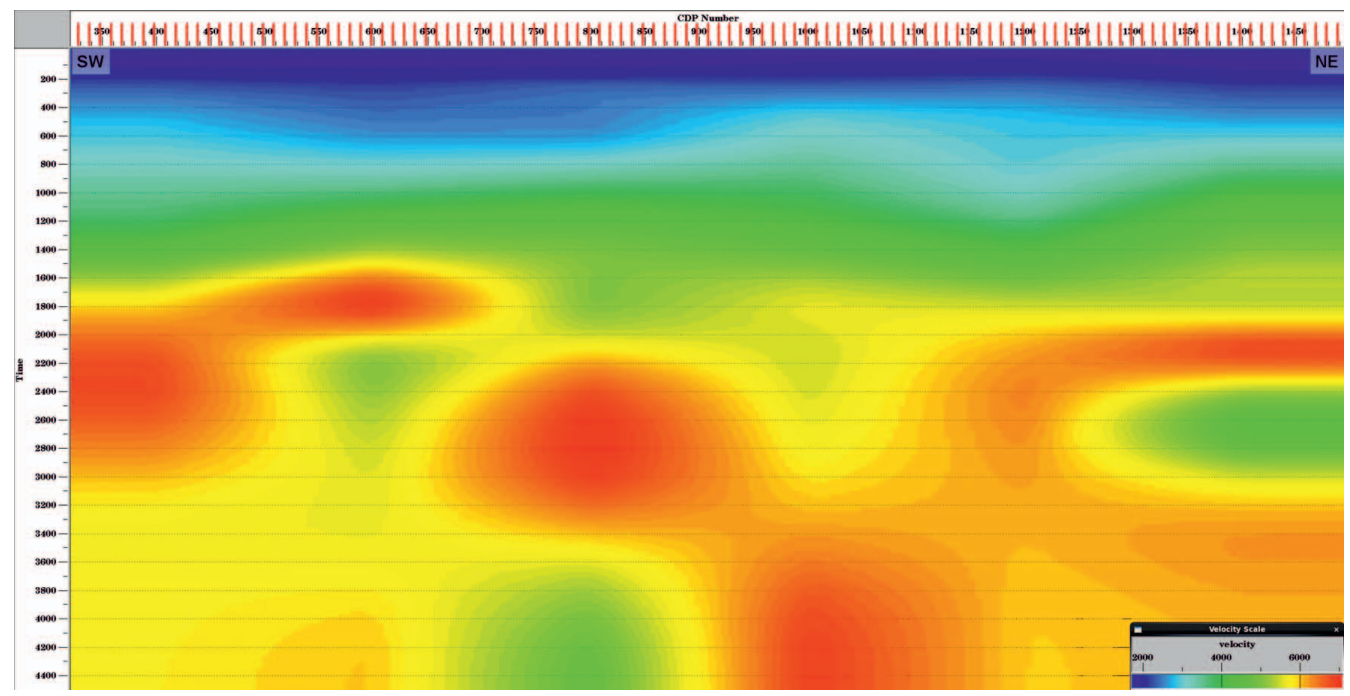

Rys. 4. Profil sejsmiczny nr 1 (rozkład prędkości interwałowych otrzymanych z analiz prędkości)

Fig. 4. Seismic profile No. 1 (distribution of interval velocities from velocity analyzes)

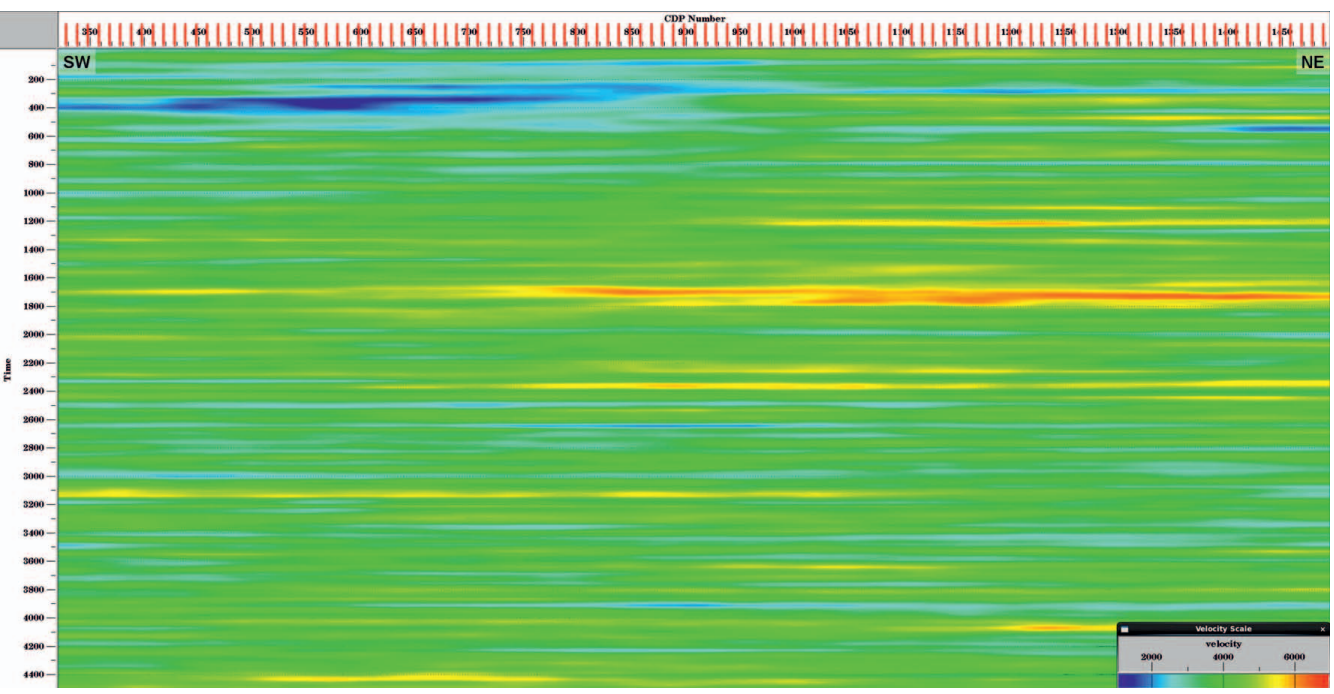

Rys. 5. Profil sejsmiczny nr 1 (rozkład prędkości interwałowych dla miąższości warstwowania $10 \mathrm{~m}$, uzyskany algorytmem rozkładu Gaussa)

Fig. 5. Seismic profile No. 1 (distribution of interval velocities for layering thickness of $10 \mathrm{~m}$, computed based on the Gaussian distribution algorithm) wykonano szereg testów różnych parametrów, takich jak: wartość procentowa prędkości, długość promienia sejsmicznego, apertura migracji, dominująca wartość częstotliwości. Migrację czasową po składaniu wykonano metodą Kirchoff’a, która uwzględnia poziome i pionowe zmiany prędkości.

\section{Analiza otrzymanych wyników}

Obrazy sejsmiczne, uzyskane w wyniku zastosowania różnych modeli prędkości do migracji czasowej po składaniu, są generalnie bardzo podobne. Różnice można zauważyć głównie w usytuowaniu i nachyleniu granic sejsmicznych w SW części profilu. W przypadku gdy granice sejsmiczne zalęgają płasko-równolegle to obraz strukturalny jest niemal identycz-

ny. Trudno jednoznacznie ocenić, który z otrzymanych obrazów sejsmicznych w bardziej wiarygodny sposób odzwierciedla budowę strukturalną badanego ośrodka. Niemniej jednak obraz sejsmiczny po migracji czasowej po składaniu z polem prędkości na bazie pomiarów PPS jest najbardziej przejrzysty spośród wszystkich uzyskanych wyników (rys. 6, 7).

Widoczne jest to głównie w SW części profilu pomiędzy trasami 142 a 322, gdzie usytuowana jest szeroka strefa dyslokacyjna. Na obrazie po migracji czasowej po składaniu w oparciu o pole prędkości na bazie pomiarów PPS przebieg dyslokacji jest lepiej widoczny, ze względu na lepsze zogniskowanie amplitud refleksów. Można to zaobserwować np. na trasie $242 \mathrm{w}$ przedziale czasu 1500-2500 ms.

Porównanie obrazu sejsmicznego na profilu po reprocessingu $\mathrm{z}$ obrazem na profilu archiwalnym (rys. 8) wypada lepiej na korzyść opracowania bieżącego. Najbardziej widoczna różnica $\mathrm{w}$ obrazach sejsmicznych obserwowana jest w częstotliwości zapisu 


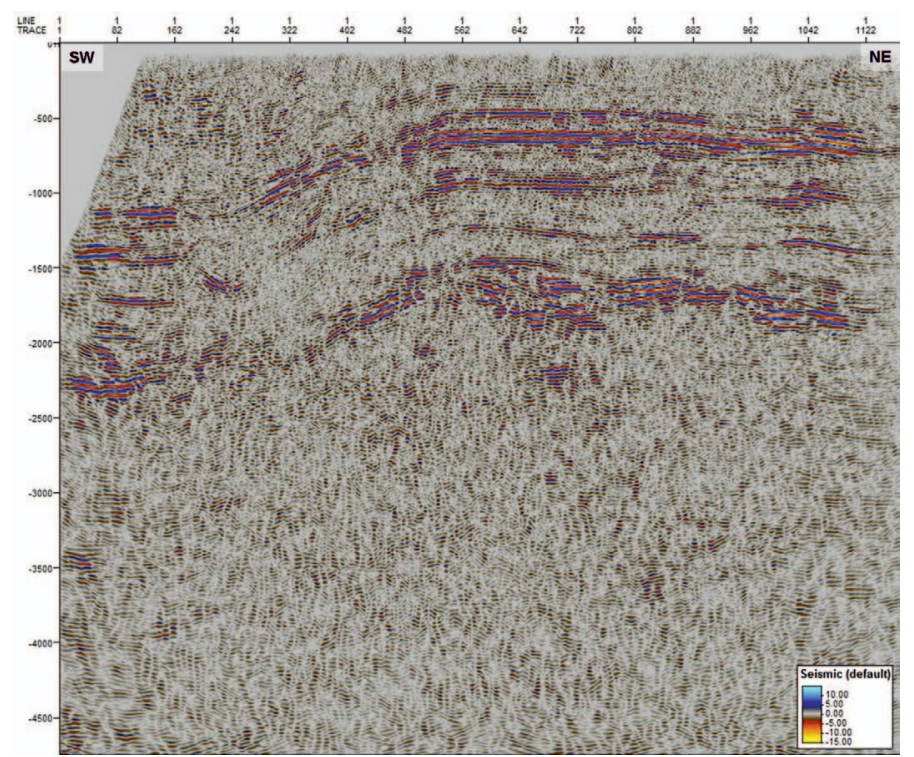

Rys. 6. Profil sejsmiczny nr 1 (migracja czasowa wykonana dla pola prędkości interwałowych, obliczona przy użyciu prędkości składania)

Fig. 6. Seismic profile No. 1 (time migration realized for the interval velocity field using stacking velocities)

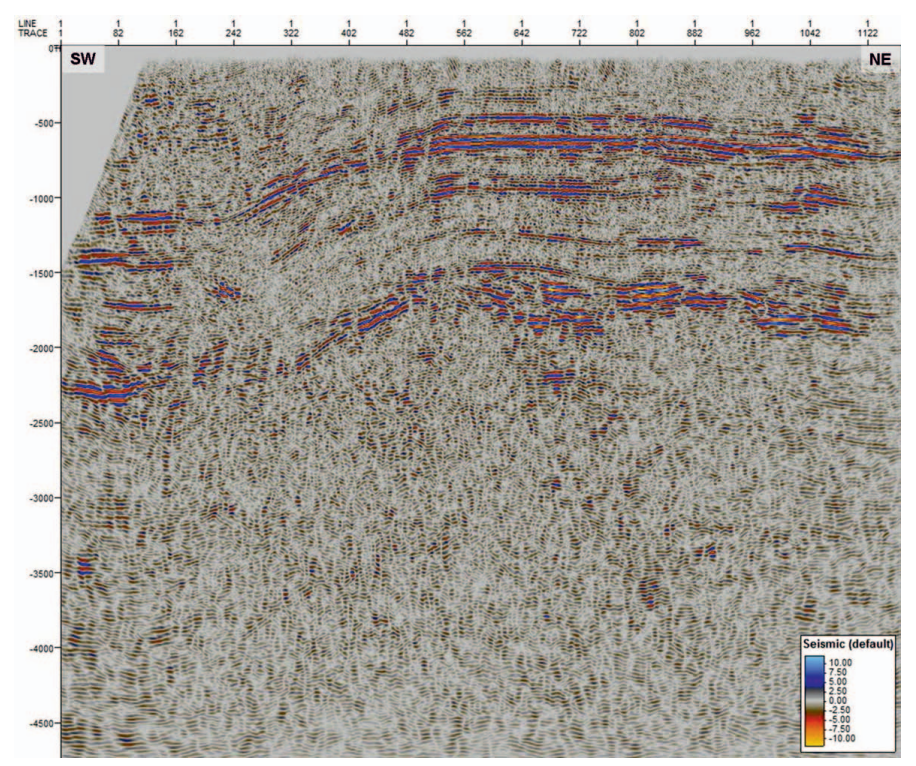

Rys. 7. Profil sejsmiczny nr 1 (migracja czasowa wykonana dla pola prędkości interwałowych dla miąższości warstwowania $10 \mathrm{~m}$ obliczonych algorytmem rozkładu Gaussa)

Fig. 7. Seismic profile No. 1 (time migration realized for the interval velocity field for layering thickness of $10 \mathrm{~m}$ computed based on the Gaussian distribution algorithm)

sejsmicznego. Warto odnotować, że zapis na wersji archiwalnej cechuje się wyraźnie wyższymi częstotliwościami w stosunku do bieżącego opracowania, co jednak paradoksalnie nie poprawia przejrzystości obrazu strukturalnego, ale wręcz utrudnia jego interpretację. Obserwowane są również różnice w wartościach i dynamice amplitud refleksów. Na wersji bieżącej pojawia się większe zróżnicowanie amplitud w stosunku do wersji archiwalnej, gdzie amplitudy są bardzo wyrównane.
Tym samym, aktualny obraz sejsmiczny lepiej odzwierciedla budowę strukturalną badanego ośrodka geologicznego. Widoczne jest to szczególnie w trakcie analizy zapisu dla stref tektonicznych i nieciągłości, gdyż na wersji bieżącej możliwa jest interpretacja zdecydowanie większej ilości stref dyslokacyjnych, zwłaszcza w obrębie utworów permsko-mezozoicznych. W wielu przypadkach obserwować można kontynuację dyslokacji przecinających utwory paleozoiczne w obręb wyższego piętra strukturalnego ( $\mathrm{tj}$. w utwory permu i mezozoiku), co potwierdza zjawisko reaktywacji starszych generacji uskoków w historii badanego rejonu. Na obrazie archiwalnym trudno jest wyinterpretować tego typu strefy tektoniczne, najprawdopodobniej głównie ze względu na znaczny stopień przemigrowania refleksów sejsmicznych, w wyniku którego płaszczyzny dyslokacji w znacznym stopniu uległy zamaskowaniu. Szczególnie dobrze widoczne jest to w odtworzeniu atrybutów sejsmicznych (rys. 10-15), które zostały obliczone zarówno dla wersji profilu po reprocessingu, jak i dla wersji archiwalnej profilu.

Atrybut Structural smoothing jest stosowany w celu poprawy ciągłości refleksów sejsmicznych (Pedersen et al., 2002). Chaos jest dedykowany głównie do rozpoznawania stref nieciągłości, natomiast RMS Amplitude, obliczany jako kwadrat amplitudy sygnału i nazywany często energią sygnału, wskazuje z kolei strefy o największej dynamice refleksów. Atrybut Structural smoothing obliczony był bezpośrednio na wersji migracji czasowej po składaniu, a pozostałe atrybuty obliczono $\mathrm{z}$ wersji po zastosowaniu Structural smoothing.

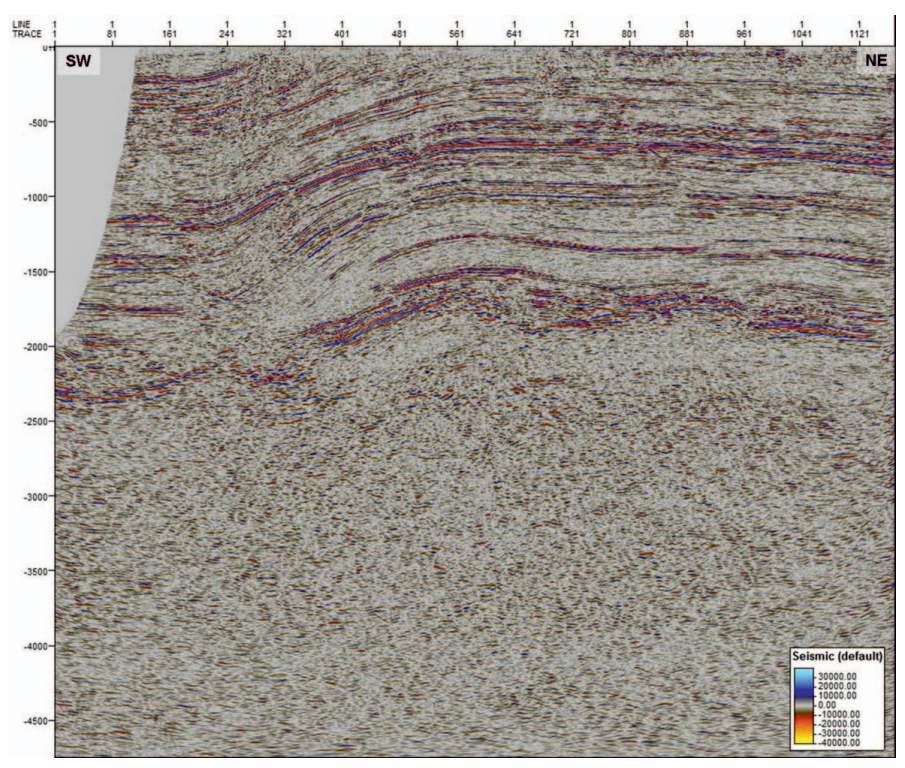

Rys. 8. Profil sejsmiczny nr 1 - wersja archiwalna (migracja czasowa)

Fig. 8. Seismic profile No. 1 - the archival version (time migration) Obliczono szereg różnych atrybutów sejsmicznych, z których na potrzeby artykułu przedstawiono: Structural smoothing, Chaos i RMS Amplitude. 


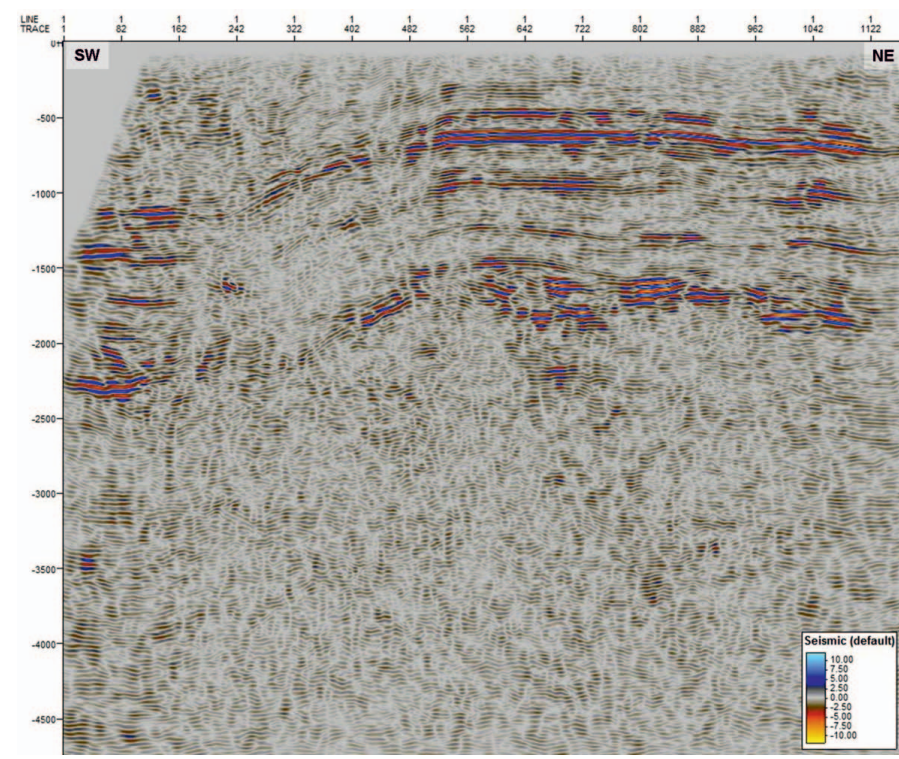

Rys. 9. Profil sejsmiczny nr 1 (poststack; przetwarzanie w INiG PIB) w odtworzeniu atrybutu Structural smoothing

Fig. 9. Seismic profile No. 1 (poststack, processing in INiG - PIB) - Structural smoothing attribute version

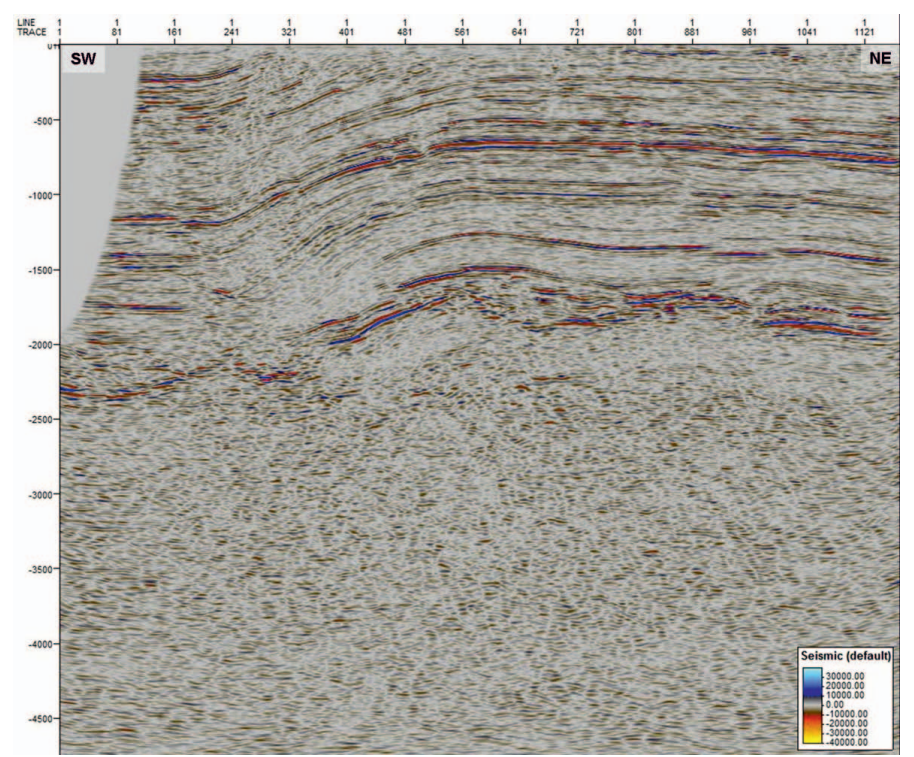

Rys. 10. Profil sejsmiczny nr 1 (poststack; wersja archiwalna) w odtworzeniu atrybutu Structural smoothing

Fig. 10. Seismic profile No. 1 (poststack, archival version) Structural smoothing attribute

W odtworzeniu atrybutu Structural smoothing ciągłość refleksów w obrazie sejsmicznym bieżącej wersji profilu jest zdecydowanie lepsza w stosunku do wersji archiwalnej migracji (rys. 9, 10). Znacznie wyraźniej odzwierciedlone zostały strefy uskokowe w obrębie utworów permo-mezozoiku, które najczęściej zakorzenione są głęboko w podłożu paleozoicznym. Szczególnie dobrze widoczna jest szeroka strefa tektoniczna w środkowej części profilu (zaznaczona kolorem różowym na rys. 16), która przecina zarówno utwory permo-mezozoiku, jak i zalegające w podłożu utwory kompleksu karbońsko-dewońskiego. Na NE od tej strefy w podłożu cechsztynu widoczne są fragmenty ciągłych refleksów sejsmicznych, zapadających w kierunku NE, które obserwować można aż do czasu około $3700 \mathrm{~ms}$. Na SW od tej strefy obraz cechuje się już zdecydowanie większym nieuporządkowaniem, niemniej i tutaj dostrzec można przynajmniej fragmenty liniujących się refleksów. W obrazie sejsmicznym tego samego atrybutu dla profilu archiwalnego nie obserwuje się tak dużego zaangażowania tektonicznego, a wspomniana wyżej strefa tektoniczna jest w zasadzie prawie niewidoczna, głównie wskutek przemigrowania refleksów. Jej ślad można jedynie częściowo zaobserwować w utworach mezozoicznych w interwale czasowym 700-750 ms (niewielki uskok zaznaczony kolorem zielonym na rys. 16) oraz w utworach cechsztyńskich i paleozoicznych w przedziale czasowym około 1700-2250 ms (zaznaczony kolorem jasnoniebieskim). Pomiędzy tymi przedziałami przebieg płaszczyzny uskoku jest w zasadzie całkowicie zatarty. Obraz sejsmiczny poniżej wartości czasu $2300 \mathrm{~ms}$, obejmujący utwory podłoża cechsztynu jawi się w postaci bezładnie rozmieszczonych niewielkich strzępów refleksów sejsmicznych.

Obraz atrybutu RMS Amplitude w większym stopniu uwidacznia znaczne zaangażowanie tektoniczne, obserwowane na sekcji sejsmicznej reprocessowanego profilu (rys. 12, 13). Widoczne są cztery główne szerokie strefy tektoniczne, które obejmują swoim zasięgiem utwory permo-mezozoiczne i kontynuują się w utwory paleozoiczne. Wspomniana już wcześniej strefa widoczna jest $\mathrm{w}$ centralnej części profilu, w przedziale tras 402-524. Na SW od niej widoczna jest kolejna strefa w przedziale tras 162-242 (zaznaczona kolorem jasnoniebieskim na rys. 15), a na NE strefy uskokowe w przedziale tras 794-826 i 903-944. Ponadto dostrzegalne są także uskoki obejmujące swym zasięgiem tylko utwory mezozoiku, lub też tylko utwory cechsztyńskie (rys. 15). Zapis tego atrybutu wskazuje również na bardzo duże zaangażowanie tektoniczne utworów paleozoiku, obserwowane zwłaszcza w środkowej części analizowanego profilu. W obrębie tych właśnie utworów wyinterpretować można wyniesioną tektonicznie strefę zrębową, której wierzchołek znajduje się w centralnej części profilu. W odtworzeniu tego samego atrybutu na wersji archiwalnej profilu tak znacznej różnicy w zapisie, sugerującej znaczne zaangażowanie tektoniczne, nie obserwuje się (rys. 12). Nieliczne (w stosunku do obrazu bieżącego) uskoki są trudne do interpretacji, a ich systemy wydają się być dosyć rozbieżne dla utworów mezozoicznych i cechsztyńskich. Obserwuje się jedynie dwie strefy uskokowe obejmujące swym zasięgiem cały kompleks permo-mezozoiczny i zagłębiające się w utwory paleozoiczne - pierwsza w SW części profilu (przedział tras 241-321), a druga w części NE (przedział tras 960-1040). Uskoki te wydają się penetrować utwory paleozoiczne do wartości czasu około $2500 \mathrm{~ms}$, a poniżej tej wartości 
obraz staje się całkowicie nieczytelny, nie pozwalając na jakąkolwiek interpretację.

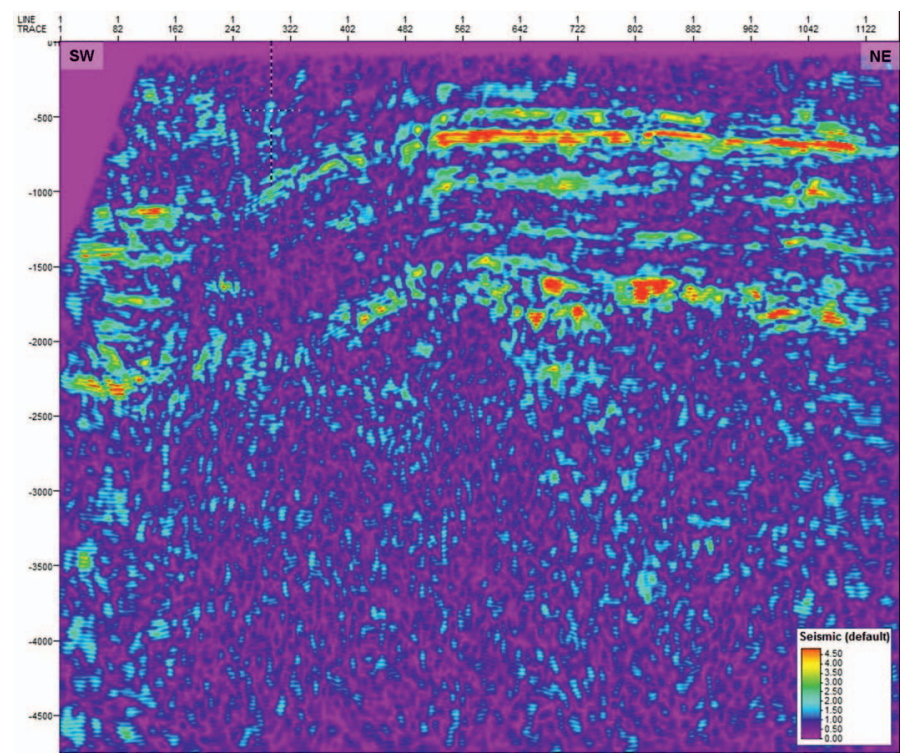

Rys. 11. Profil sejsmiczny nr 1 (poststack; przetwarzanie w INiG PIB) w odtworzeniu atrybutu RMS Amplitude

Fig. 11. Seismic profile No. 1 (poststack, processing in $\mathrm{INiG}-$ PIB) - RMS Amplitude attribute

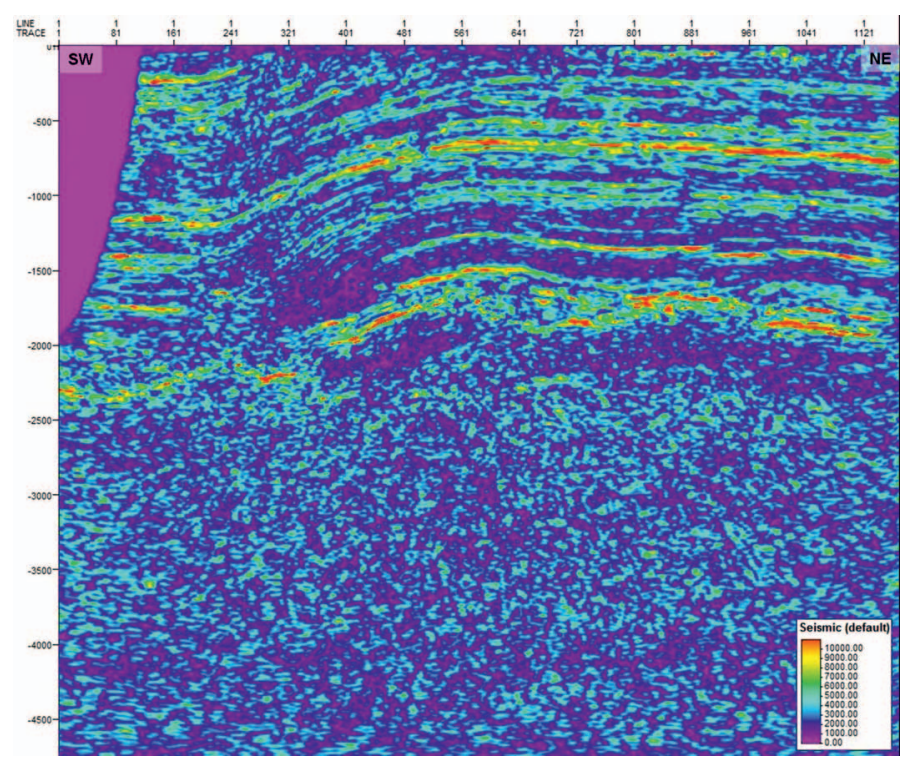

Rys. 12. Profil sejsmiczny nr 1 (poststack; wersja archiwalna) w odtworzeniu atrybutu RMS Amplitude

Fig. 12. Seismic profile No. 1 (poststack, archival version) - RMS Amplitude attribute

W odtworzeniu atrybutu Chaos obraz na reprocessowanym profilu (rys. 13) wskazuje na jeszcze większe zaangażowanie tektoniczne niż w wersjach atrybutów omówionych powyżej. Można tutaj zaobserwować szereg niewielkich nieciągłości w całym przedziale rejestracji sejsmicznej. W podłożu paleozoicznym wyraźnie widoczna jest wspomniana wyżej strefa zrębowa, która najprawdopodobniej miała duży wpływ na rozwój strukturalny i obecny układ utworów permo-mezozoiku. Obraz omawianego atrybutu wskazuje, że dyslokacje obserwowane w obrębie utworów permo-mezozoiku niewątpliwie tworzyły się na bazie reaktywacji starszych założeń tektonicznych (przypuszczalnie hercyńskich). Na wersji archiwalnej omawianego atrybutu obraz jest zasadniczo różny (rys. 14). Generalnie uwypuklona została jedynie szeroka strefa tektoniczna w SW części profilu. Obraz paleozoiku w podłożu cechsztynu w odtworzeniu atrybutu Chaos w wersji archiwalnej w zasadzie nie nadaje się do interpretacji (rys. 14).

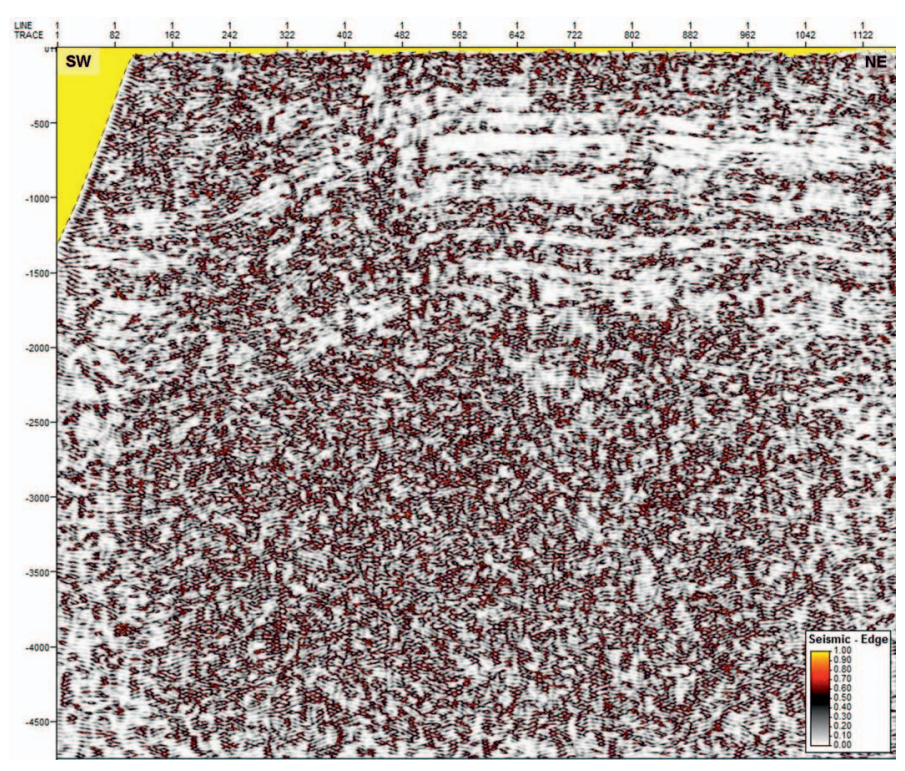

Rys. 13. Profil sejsmiczny $\mathrm{nr} 1$ (poststack; przetwarzanie w INiG PIB) w odtworzeniu atrybutu Chaos

Fig. 13. Seismic profile No. 1 (poststack, processing in INiG PIB) - Chaos attribute

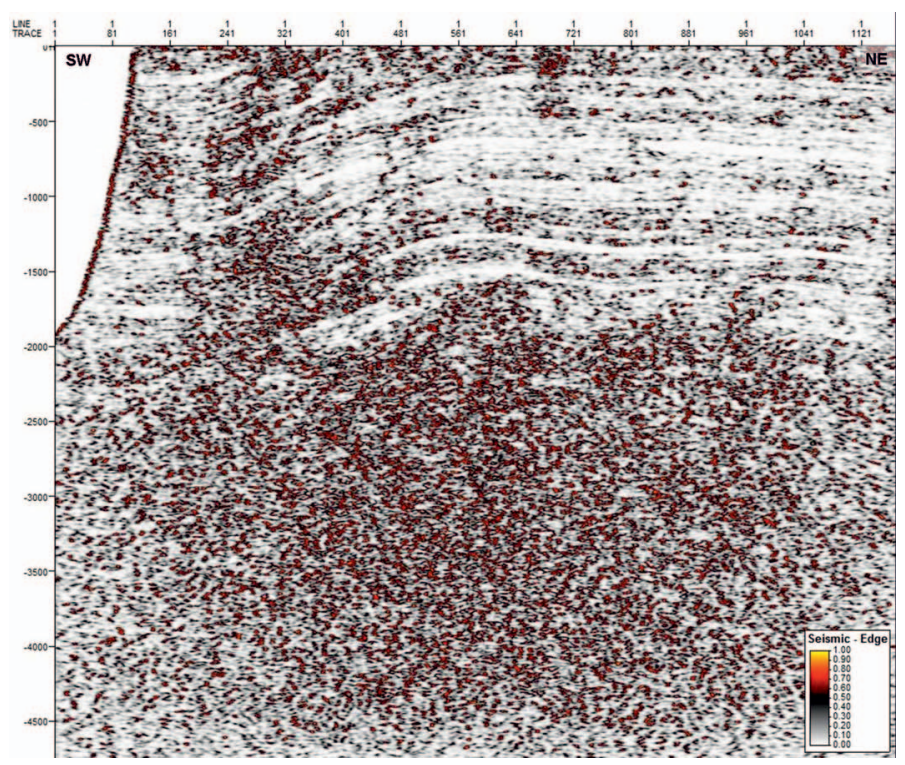

Rys. 14. Profil sejsmiczny nr 1 (poststack; wersja archiwalna) w odtworzeniu atrybutu Chaos

Fig. 14. Seismic profile No. 1 (poststack, archival version) Chaos attribute 
Na podstawie przeprowadzonej analizy, opartej o wybrane wersje atrybutów sejsmicznych, można stwierdzić, że zdecydowanej poprawie uległ obraz sejsmiczny w obrębie utworów cechsztynu i mezozoiku. Uzyskany obraz dla utworów podcechsztyńskich, który był głównym przedmiotem tej pracy, pomimo iż pozwala on na fragmentaryczną interpretację strukturalną (w stosunku do archiwalnego opracowania), nie jest w pełni zadowalający. Obraz ten nie odzwierciedla bowiem szczegółów budowy geologicznej tego piętra i nie pozwala na jego wiarygodną interpretację strukturalną.

\section{Interpretacja strukturalna}

Na rysunkach 15 i 16 dla porównania przedstawiono profil $\mathrm{nr} 1 \mathrm{w}$ wersji archiwalnej i wersji po reprocessingu wraz $\mathrm{z}$ interpretacją strukturalną.

Korelowane granice dowiązano w następujący sposób:

- TkV - odbicie od spągu retyku/stropu kajpru, śledzone po maksimum amplitudowym;

- TmV - odbicie od stropu wapienia muszlowego, śledzone po maksimum amplitudowym;

- Z4 - odbicie od stropu cechsztynu, śledzone po minimum amplitudowym;

- A3_str - odbicie od stropu anhydrytu głównego, korelowane po maksimum amplitudowym;

- A2_str - odbicie od stropu anhydrytu podstawowego, korelowane po maksimum amplitudowym;

- Zsp - odbicie od spągu cechsztynu, korelowane po minimum amplitudowym;

- Cstr - odbicie od stropu karbonu, korelowane po maksimum amplitudowym.

Granice te dowiązane zostały do reperów stratygraficznych w najbliżej usytuowanym otworze W-1, który znajduje się w odległości około $790 \mathrm{~m}$ od reprocessowanego profilu. Ze względu na jego dużą odległość od profilu, jak również na fakt, iż sejsmika nie spełnia kryteriów zerofazowości (zarówno dla wersji bieżącej, jak i archiwalnej) dopasowanie było dosyć problematyczne, zwłaszcza w utworach cechsztynu. $Z$ tego powodu zrezygnowano również z wykonania sejsmogramu syntetycznego dla wspomnianego otworu. Wobec powyższego korelacja sejsmiczna nie jest jednoznaczna, zwłaszcza w utworach cechsztynu, jak również dla granicy odpowiadającej stropowi karbonu. Odnosi się to zarówno do wersji bieżącej, jak i archiwalnej profilu.

Wersja bieżąca migracji po składaniu pozwala jednak na fragmentaryczną interpretację granic w utworach podcechsztyńskich, w przeciwieństwie do wersji archiwalnej, na której taka interpretacja nie jest możliwa. Istotną różnicę zauważyć można w przypadku interpretacji tektonicznej analizowanego profilu. Na wersji bieżącej po reprocesingu obraz sejsmiczny pozwala na wyinterpretowanie wielu stref dyslokacyjnych, które nie są widoczne na wersji archiwalnej. Tym samym przedstawiona wersja interpretacji prezentuje odmienny i bardziej szczegółowy obraz budowy geologicznej analizowanego rejonu w porównaniu z wersją archiwalną. Obecny model geologiczny wydaje się znacznie bardziej odpowiadać historii tektonicznej badanego rejonu, w porównaniu do zapisu sejsmicznego na profilu archiwalnym.

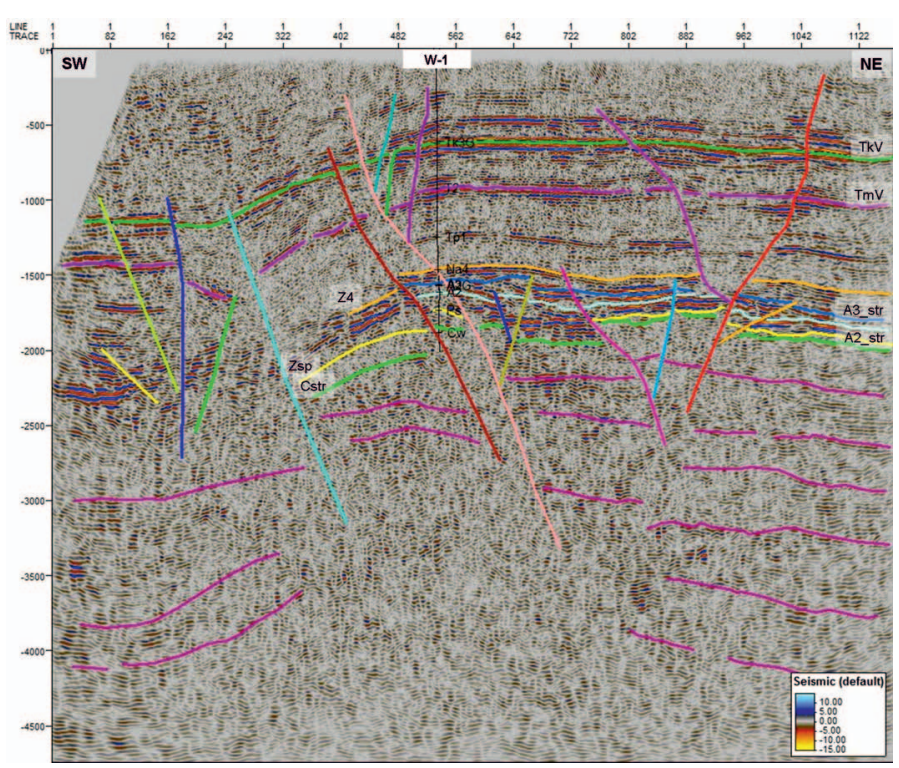

Rys. 15. Profil sejsmiczny nr 1 (migracja czasowa wykonana dla pola prędkości interwałowych dla miąższości warstwowania $10 \mathrm{~m}$, obliczonych algorytmem rozkładu Gaussa z interpretacją strukturalną)

Fig. 15. Seismic profile No. 1 (time migration realized for the interval velocity field for layering thickness of $10 \mathrm{~m}$ computed based on the Gaussian distribution algorithm_with structural interpretation)

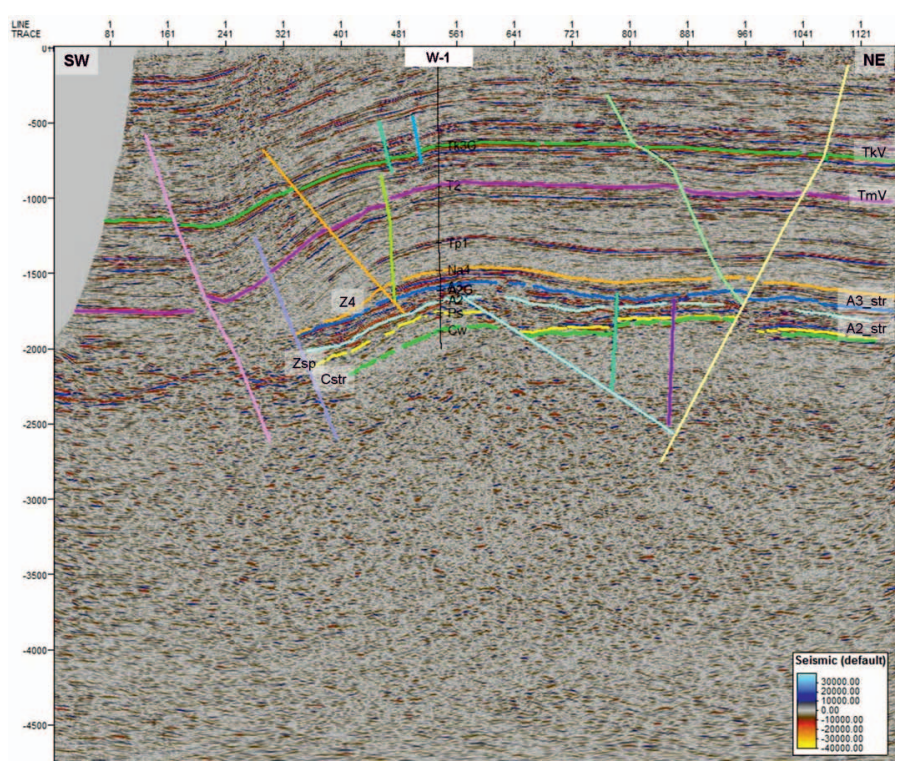

Rys. 16. Profil sejsmiczny nr 1 (migracja czasowa - wersja archiwalna profilu $\mathrm{z}$ interpretacja strukturalną)

Fig. 16. Seismic profile No. 1 (time migration - archival version of the profile with_structural interpretation) 


\section{Podsumowanie i wnioski}

Zastosowana obecnie sekwencja przetwarzania pozwoliła na zdecydowaną poprawę obrazu sejsmicznego, głównie w obrębie utworów permo-mezozoicznych. Najbardziej istotna różnica związana jest ze znacznie lepszą możliwością śledzenia przebiegu stref dyslokacyjnych. Przekłada się to przede wszystkim na możliwość nowej wersji interpretacji strukturalnej, przedstawiającej znacznie większy stopień komplikacji tektonicznej rejonu w stosunku do obrazu widocznego na wersji archiwalnej profilu.

Pewnej poprawie uległ również obraz sejsmiczny w podłożu cechsztynu, co było głównym celem niniejszej pracy, jednak nie jest to obraz w pełni satysfakcjonujący. Uzyskany na obecnym etapie obraz daje możliwość przynajmniej fragmentarycznej korelacji granic sejsmicznych w podłożu cechsztynu, pozwalając tym samym na uzyskanie zarysu obrazu strukturalnego tych utworów, jak również dokumentuje obecność dużych stref dyslokacji, które kontynuują się w utwory piętra permo-mezozoicznego. Dyslokacje te (przypuszczalnie o założeniach hercyńskich) ulegały następnie reaktywacji w kolejnych etapach rozwoju tektonicznego badanego obszaru.

Główną przyczyną braku czytelnego i w pełni wiarygodnego obrazu strukturalnego w zapisie sejsmicznym dla utworów podłoża cechsztynu jest najprawdopodobniej brak poprawnego rozkładu prędkości w ich obrębie, wynikający z niedostatecznej ilości danych. Analiza prędkości składania w tym przedziale czasowym jest obarczona zbyt dużymi błędami, a brak danych otworowych nie pozwala na konstrukcję poprawnego modelu prędkości do migracji.

Wyniki prezentowanej pracy pokazują, że nadal istnieje duży potencjał w zakresie reprocesing $u$ archiwalnych profili sejsmicznych z analizowanego rejonu, a wysiłki w celu uzyskania lepszego obrazu sejsmicznego dla utworów podłoża cechsztynu powinny się koncentrować głównie na poprawnym odwzorowaniu pola prędkości w ich obrębie. W dalszych etapach badań należy wykonać migrację czasową przed składaniem oraz migrację głębokościową. Obydwa typy migracji, ze względu na stosowane w nich algorytmy, powinny pozwolić na bardziej szczegółowe odzwierciedlenie budowy geologicznej utworów podcechsztyńskich. Tym samym prace zmierzające do poprawy zapisu sejsmicznego tych utworów w obszarze Pomorza Zachodniego powinny być kontynuowane.

Artykuł powstał na podstawie pracy statutowej pt.: Poprawa obrazowania struktur podcechsztynskich na podstawie reprocessingu sejsmiki $2 D$ w rejonie Pomorza Zachodniego - praca INiG - PIB na zlecenie MNiSW; nr zlecenia 0031/SR/18, nr archiwalny DK-4100-0031/18.

\section{Literatura}

Bajewski Ł., Urbaniec A., Wilk A., Bartoń R., 2016. Zwiększenie dokładności odwzorowania ośrodka geologicznego z obszaru Karpat na podstawie przetwarzania sejsmiki powierzchniowej 2D i otworowej. Praca statutowa. Kraków: Archiwum Instytutu Nafty i Gazu - Państwowego Instytutu Badawczego.

Bajewski Ł., Urbaniec A., Wilk A., Bartoń R., 2017a. Poprawa dokładności odwzorowania budowy geologicznej w obrazie sejsmicznym z obszaru Karpat zewnętrznych. Nafta-Gaz, 7: 447-454. DOI: 10.18668/NG.2017.07.02.

Bajewski Ł., Urbaniec A., Wilk A., Bartoń R., 2017b. Zwiększenie dokładności odwzorowania ośrodka geologicznego z obszaru Karpat na podstawie przetwarzania sejsmiki powierzchniowej 2D i otworowej. Cz. II. Praca statutowa. Kraków: Archiwum Instytutu Nafty i Gazu - Państwowego Instytutu Badawczego.

Bajewski Ł., Wilk A., Bartoń R., Urbaniec A., 2018a. Zwiększenie dokładności odwzorowania ośrodka geologicznego z wybranego obszaru Karpat zewnętrznych na podstawie reprocessingu archiwalnych profili sejsmicznych 2D. Kraków: Prace Naukowe Instytutu Nafty i Gazu - Państwowego Instytutu Badawczego, 222: 1-180.

Bajewski Ł., Wilk A., Urbaniec A., Bartoń R., 2018b. Poprawa obrazowania struktur podcechsztynskich na podstawie reprocessingu sejsmiki 2D w rejonie Pomorza Zachodniego. Praca statutowa. Kraków: Archiwum Instytutu Nafty i Gazu - Państwowego Instytutu Badawczego.

Dadlez R., 1978. Podpermskie kompleksy skalne w strefie KoszalinChojnice. Kwartalnik Geologiczny, 22: 269-301.

Grad M., Keller G.R., Thybo H., Guterch A., 2002. POLONAISE Working Group - Lower lithospheric structure beneath the TransEuropean Suture Zone from POLONAISE'97 seismic profiles. Tectonophysics, 360: 153-168.

Matyja H., 1993, Upper Devonian of West ern Pomerania. Acta Geol. Pol., 42: 27-94.

Matyja H., 2006. Stratygrafia i rozwój facjalny osadów dewonu i karbonu w basenie pomorskim i w zachodniej części basenu bałtyckiego a paleogeografia północnej części TESZ w późnym paleozoiku. Prace Państwowego Instytutu Geologicznego, 186: 79-122.

Matyja H., Turnau E., Żbikowska B., 2000. Lower Carboniferous (Missisippian) stratigraphy of northwestern Poland: conodont, miospore and ostracod zones compared. Ann. Soc. Geol. Pol., 70: 193-217.

Nawrocki J., Poprawa P., 2006. Development of Trans-European Suture Zone in Poland: from Ediacaran rifting to Early Palaeozoic accretion. Geol. Quart., 50(1): 59-76.

Pedersen S.I., Randen T., Sønneland L., 2002. Automatic extraction of fault surfaces from three-dimensional seismic data. Expanded Abstract, Int. Mtg., Soc. Exploration Geophys., 512-515.

Pharaoh T.C., 1999. Palaeozoic terranes and their lithospheric boundaries within the Trans-European Suture Zone (TESZ): a review. Tectonophysics, 314: 17-41.

Świdrowska J., Hakenberg M., 1996. Palaeotectonic evolution of the Koszalin-Chojnice Late Devonian basin (Western Pomerania, Northern Po land). Bull. Pol. Acad. Sc. Earth Sc., 44: 17-36.

Wagner R., 1994. Stratygrafia i rozwój basenu cechsztyńskiego na Niżu Polskim. Prace Państwowego Instytutu Geologicznego, 146: 1-71.

Wilk A., Bartoń R., Bajewski Ł., Urbaniec A., 2017. Budowa pola prędkości na potrzeby migracji czasowej i głębokościowej 2D, przed i po składaniu w trudnych rejonach geologicznych. Praca statutowa. Kraków: Archiwum Instytutu Nafty i Gazu Państwowego Instytutu Badawczego. 
Wilk A., Bartoń R., Bajewski Ł., Urbaniec A., 2018. Budowa pola prędkości na potrzeby migracji czasowej po składaniu w trudnych rejonach geologicznych na przykładzie Karpat fliszowych w południowo-wschodniej Polsce. Nafta-Gaz, 10: 723-731.
Żelaźniewicz A., Aleksandrowski P., Buła Z., Karnkowski P.H., Konon A., Oszczypko N., Ślączka A., Żaba J., Żytko K., 2011. Regionalizacja tektoniczna Polski. Wrocław: Komitet Nauk Geologicznych PAN.

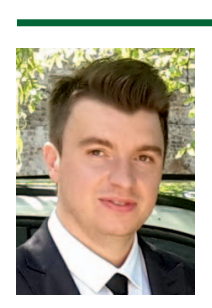

Mgr inż. Łukasz BAJEWSKI

Główny specjalista inżynieryjno-techniczny

w Zakładzie Sejsmiki

Instytut Nafty i Gazu - Państwowy Instytut Badawczy

ul. Lubicz 25 A

31-503 Kraków

E-mail: lukasz.bajewski@inig.pl

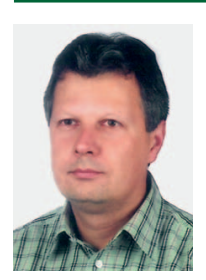

Mgr Andrzej URBANIEC

Główny specjalista inżynieryjno-techniczny

w Zakładzie Sejsmiki

Instytut Nafty i Gazu - Państwowy Instytut Badawczy ul. Lubicz 25 A

31-503 Kraków

E-mail:andrzej.urbaniec@inig.pl

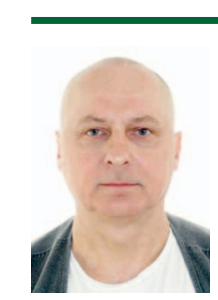

Mgr inż. Aleksander WILK

Główny specjalista inżynieryjno-techniczny

w Zakładzie Sejsmiki

Instytut Nafty i Gazu - Państwowy Instytut Badawczy ul. Lubicz 25 A

31-503 Kraków

E-mail:wilka@inig.pl

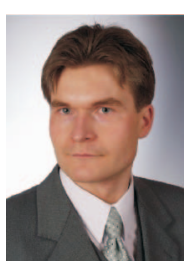

Dr inż. Robert BARTOŃ

Adiunkt w Zakładzie Sejsmiki

Instytut Nafty i Gazu - Państwowy Instytut Badawczy

ul. Lubicz 25 A

31-503 Kraków

E-mail: robert.barton@inig.pl

\section{OFERTA}

\section{ZAKŁAD SEJSMIKI}

Zakres działania:

- $\quad$ interpretacja strukturalna i litofacjalna zdjęć sejsmicznych 2D i 3D;

- $\quad$ przetwarzanie danych sejsmicznych 2D/3D Prestack i Postack;

- migracja sejsmiczna MGF-K w wersji Prestack i Postack w domenie czasu i głębokości z uwzględnieniem anizotropii ośrodka typu VTI, TTI, HTI;

- $\quad$ interpretacja strukturalna i litofacjalna pomiarów sejsmicznych Prestack i Postack 2D oraz 3D;

- $\quad$ przetwarzanie i interpretacja pionowych profilowań sejsmicznych PPS 1C, 3C;

- budowa modeli prędkościowych na podstawie analiz danych sejsmicznych i geofizycznych w domenie czasu i głębokości - konwersja czas-głębokość, migracja głębokościowa;

- $\quad$ interpretacja danych sejsmicznych 3D-3C oraz pomiarów sejsmiki otworowej PPS-3C;

- $\quad$ konstrukcja map powierzchniowych - czasowych i głębokościowych;

- zwiększenie dokładności identyfikacji ośrodka geologicznego poprzez modyfikację charakterystyki widmowej zarejestrowanych danych sejsmicznych;

- poprawa rozdzielczości danych sejsmicznych Postack - dekompozycja spektralna;

- $\quad$ wieloatrybutowa charakterystyka ośrodka geologicznego;

- $\quad$ analizy sejsmiczne AVO, AVAZ;

- obliczanie inwersji symultanicznej oraz stochastycznej;

- $\quad$ wykonywanie modelowania sejsmicznego

- $\quad$ identyfikacja anizotropii typu HTI w ośrodku geologicznym przy użyciu danych sejsmicznych i otworowych - określenie intensywności oraz azymutu anizotropii;

- obliczanie parametrów anizotropii typu VTI i HTI oraz określenie głównych kierunków szczelinowatości na podstawie wieloazymutalnego pomiaru PPS 3 C i sejsmiki powierzchniowej;

- $\quad$ wyznaczanie poziomów zlożowych (bright, dim oraz sweet spot) na danych Prestack oraz Postack:

- zastosowanie metod geostatycznych do konstrukcji statycznych i dynamicznych modeli złóż węglówodorów:

- $\quad$ prognozowanie ciśnień porowych na podstawie danych sejsmicznych i geofizycznych.

P. o. Kierownika: mgr inż. Aleksander Wilk

Adres: ul. Bagrowa 1, 30-733 Kraków

Telefon: 126177480

Faks: 126531665

E-mail: aleksander.wilk@inig.pl

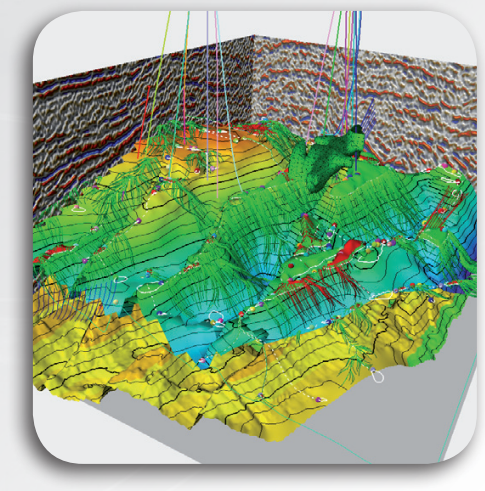

